\title{
Digital University Models in the Process of Modern Transformation of Higher Education
}

\author{
Doroshenko T.N. \\ Yaroslav-the-Wise Novgorod State University, \\ Veliky Novgorod, Russia, \\ tatyana.doroshenko@novsu.ru
}

\author{
Kalpinskaya O.E. \\ Yaroslav-the-Wise Novgorod State University, \\ Veliky Novgorod, Russia, \\ olga.kalpinskaya@novsu.ru
}

\author{
Makarova E.A. \\ Yaroslav-the-Wise Novgorod State University, \\ Veliky Novgorod, Russia, \\ Elena.Makarova@novsu.ru
}

\begin{abstract}
The article is devoted to the topical issue of modeling the mechanisms of introducing digital technologies into the educational process of academic universities, the intensity of which increases in proportion to the challenges and threats of modern society. The authors record the cardinal changes in university education under the influence of digitalization in the forms and methods of teaching, management of the learning process, working conditions of teachers, staff and students, linking the main directions of such a transformation with the use and implementation, to one degree or another, of "digital university" models. The essential characteristics of each model are the automation of administrative processes, the scale and quality of the implementation of e-learning technologies (including synchronous and asynchronous methods of studentteacher-employee interaction), the quantitative increase in IT specialists and the possibility of building up the corresponding digital competencies among graduates of all directions, ensuring the transition to digital models of real and organizational objects and the creation of a digital footprint of the subjects of the educational process. Based on the analysis of the positive experience of implementation and the problems that hinder the active implementation of these models, the general key approaches of the digital agenda and the general strategy of universities are identified, which make it possible to determine the prospects for the competitiveness of universities as providers of services in higher education in the context of the changed demands of modern society.
\end{abstract}

Keywords - digitalization of education, digital university, elearning, distance education technologies, IT competencies, digital footprint

\section{INTRODUCTION}

The modern post-industrial world demonstrates the constant acceleration and improvement of technological processes in various spheres of industrial and social life.
Digital reality has firmly entered modern life with the ubiquitous use of mobile devices, social networks as the main means of communication, geolocation sensors and cloud computing. Researchers of the processes of transformation of society conclude that digitalization has a complex, systemic nature: digital reality today captures all spheres of the economy, politics, communication, closely intertwining with traditional "living" social relations $[1,2]$.

But the era of IT technologies, along with enormous opportunities and prospects, in parallel creates new difficulties. Global problems (including the pandemic) forced to dramatically accelerate the process of introducing new digital technologies into the educational process, which entailed a transformation of the educational, research and management space of universities and an increase in the differentiation of the country's university landscape as a whole, supported by a number of state programs [3]. The researchers note that the fact that digital resources, changing the educational landscape and technologies, are changing traditional teaching, ranging from the choice of a teacher, the time of mastering educational programs, and ending with the forms and methods of pedagogical activity [4]. The development of the graduate's creative competence as the goal of the educational process today occurs not only in the classroom, but to a greater extent as a result of a long-term independent unregulated work of the student using network tools and online materials [5, 6].

When defining models for the transformation of universities, it is important to identify the features of the use of digital technologies that affect the relationship between the subjects of educational services. What has changed is, first of all, students, whose demands and expectations have increased dramatically in the last decade, and which modern service providers in the field of higher education must meet. In the 
information environment, applicable to young people, the term "digital generation" has developed as a generation that actively and successfully uses digital technologies for educational and personal purposes [7]. Universities are considered by today's applicants and students to a greater extent as the basis for their future employment. Hence the change in the functions of the university as a center for providing new rapidly changing demands, capable of demonstrating digital experience that meets the requirements of the labor market, society and economy. Digitalization is designed to bring benefits, expressed in improving the quality of mastering competencies, employing graduates and reducing student dropout rates. Digital technologies have a number of advantages over analog technologies that can be used by universities: it is more convenient and safer to store information, because noise immunity of digital systems allows you to store, retrieve and restore data without damage and wear and tear [8].

New technologies (electronic "smart" devices and sensors, cloud resources, etc.) make it possible to rethink the process and teaching methods in the direction of increasing teaching efficiency. Using platforms to create and use internal and external (massive open) online courses scales educational spaces.

Of course, the nature of the changes will be different in degree and depth in a single university, but we believe that there are some common key approaches of the digital agenda and the general strategy of universities that allow modernizing the transformation format, which is explored in this paper.

\section{FINDINGS}

The first and simplest model of "digitalization" that universities have been implementing since the advent of calculating solvers is associated with the automation of administrative processes. It is hard to imagine any university that does not use 1C software products (accounting, personnel, document management, etc.). Only a few universities do not digitize the accumulation and storage of data for subsequent use in administration [9]. A number of researchers believe that this situation is due to some "deformation" in managerial tasks, such as building relationships with executive authorities, promoting the university in the Internet space. It is these tasks that push aside the primary tasks of digitalizing the internal processes of the university, analyzing changing applicants and students as such in a new era, implementing research policy, building international relations and relations with business communities [10].

The second model of "digitalization of the university", which began to be implemented fragmentarily more than 30 years ago, and has been rapidly progressing over the past 10 years, is the introduction of online education. Among the main features of "digital universities" is the formation and implementation of new resources for the educational process, which increase the space of the university by developing its own and attracting massive open online courses. Thanks to these resources, one can talk about the so-called blended learning and the emergence of a new task of digitizing scientific and educational content with subsequent integration with existing services, or designing such services [11].

The implementation, use and dissemination of blended learning, in which a previously unused distance form appears, poses new challenges for teachers and expands their functions. Now the teacher must not only form educational content, but also be able to adapt it for educational purposes, digitize this content, as well as guide, motivate students and stimulate their cognitive competencies.

Thus, speaking about the characteristics of distance learning, we can name the following: the emergence of greater self-control of the teacher, the presence of modularity, the expansion of the teacher's role, the separation of the actors of the educational process by physical distance, the virtuality of the learning environment, a decrease in the controlling function of the teacher, the use of completely new forms and methods of teaching [12]

Some universities began to practice on a large scale the introduction of a large volume of online courses into the educational process for their students, for example, the Higher School of Economics. Many universities are moving along the path of combining offline classes and MOOCs in teaching one discipline. Asynchronous access is convenient for the student (the ability to study at any time), but creates the danger of a complete abandonment of traditional classroom education with a loss of motivation for full-time studies. The large-scale market of domestic and foreign online courses allows students to study the most popular of them, courses which were developed by leading experts in the relevant field. This situation leads to the fact that the danger of losing the pluralism of approaches to the content of education increases [13].

The third model of digitalization, which also has a long history of its existence, is the use of synchronous distance technologies in the learning process when it is completely or partially impossible for the teacher and (or) students to be in the classroom. Today there are a sufficient number of synchronous video conferencing platforms (Skype, Microsoft Teams, Zoom, etc.) for conducting various types of classes, which was clearly manifested during the current pandemic. Requirements for the volume, the form of classes in a synchronous form, the ethical aspects of interaction between the student and the teacher, was set by each university independently, simultaneously defining the criteria for quality control of the educational process.

If the rapid introduction of online courses (the second model of digitalization) was hampered by the lack of the necessary methodological and technological training of teachers, then synchronous forms of "live" communication spread relatively easily. The advantage is that online consultations conducted by both teachers and other employees of the university for students are not at all institutionalized on the site of the university website [11], and requires expensive investments in digital equipment.

The second and third models of the "digital" university are essentially elements of e-learning - teaching and learning using information technologies, implying the use of various electronic media for the implementation of the educational process, on the Web and outside of it. Education is implemented through the use of various methods, techniques and forms (including online games and simulators, electronic encyclopedia dictionaries, forums and blogs, paid and free online courses within Learning management systems (LMS) and massive open online courses (MOOCs) [14] 
The essence of the fourth model of the "digital university" is to increase IT specialists and build up the corresponding digital competencies. It seems that in comparison with the previous models, it is more organizationally complex, since it comes down to the need to introduce a new block of IT competence into the core of the educational process. Examples of such reorganization were the introduction of a certain amount of materials and competencies in physics and mathematics half a century ago (to meet the demands of the industrial revolution) or the English language and economics in the 1990s (under the requests of the "openness" of the country and market forms). Then they tried to introduce the economy, with varying success. But the peculiarity of the formation of IT competence is that it is not an element of fundamental education, but of basic literacy. The determining factor in this process is the emergence and formulation of students' skills and abilities of selforganization and self-education that were not previously formed on such a scale [15].

Some universities have solved this problem radically and introduced the discipline of IT technology into the educational core totally for "physicists and lyricists". It is often difficult to do this organizationally, because a large staff of qualified teachers will be required. The problem also lies in the lack of the proper digital competence of the administration and the teaching staff, who are often less literate in this area than students, causing the latter to dismiss the current state of IT literacy among university staff.

The fifth model of the "digital university" is based on the mass qualified training of IT specialists throughout the country, which is documented in the administrative acts of the educational authorities, fixing the number of control figures for admission to universities for the relevant specialties. This is a kind of state contribution to the development of "digital universities", which has been multiplied in our country. An increase in the training of specialists in areas directly related to the IT sphere, in addition to information technologists (applied mathematics, partly radio engineering, information security, etc.), will provide an opportunity for a personnel "breakthrough" in the state. The task of a particular university in this process is to prevent a drop in the quality of training of qualified specialists, to come up with forms and methods of ensuring this process, which should be one of the main strategies of educational policy.

The transition to digital models of real and organizational objects is the sixth model of the "digital university". First of all, we are talking about the transition to digital models and digital twins in practice-oriented learning, which allows to increase the speed of manufacturing and testing of real products, which do not allow achieving the effects of traditional prototyping. There is nothing fundamentally new here, the problem can be solved with the availability of modern technical capabilities of computer equipment that allows the modeling of such objects, their digital interpretation, in order to minimize the amount of work with real objects.

Modeling of organizational systems rather than natural physical objects is less developed. It is implemented in practice through various simulators, game approaches, in which reality is replaced by various kinds of digital models, and a real situation is played on them. Due to the use of digital models, the term for the formation of high-quality competence is sharply reduced. Thus, we can talk about the transition to the digital educational process as the core of the sixth model of the "digital university".

The seventh model of the "digital university" lies in the plane of creating a true digital footprint, which is left by the subjects of the educational process. The digital footprint in this case is a reflection of the individual trajectory, the preservation and analysis of the courses and modules studied, a variety of learning artifacts (essays, reflections, qualification papers, dissertations, and other things) recorded in digital texts, visual information that can be deciphered. The digital footprint allows one to correlate the manifestation of each movement in the world of knowledge with a certain model of competencies; allows you to identify the resource potential of a student for a particular form and field of activity (for example, to determine the propensity for research or practiceoriented activities). If one approaches this process professionally, carefully and automatically, then it is possible to successfully form a graduate's competence profile.

\section{CONCLUSION}

Thus, it can be stated that the higher education system as a whole and the organization of the educational process in universities are constantly changing.

The conveyor of mass education with the end result of the release of specialists from the "one program" to the labor market with new realities becomes irrelevant. The value of possessing knowledge and awareness in a certain area is no longer enough in the context of the volume and availability of information in the digital environment; it is necessary to teach how to navigate this sea of information and to correctly choose the necessary material and tools for its processing [16].

The need of universities to fight for students, teachers and funding forces educational institutions to keep pace with the times and actively use new digital opportunities to ensure competitiveness in the educational services market.

Many universities are developing specific digital strategies in response to the massive shift to new technologies. But they often lack the foresight, capabilities, or sustained commitment to their effective implementation, which leads to the lack of expected benefits and results when investing sufficiently significant funds in an attempt to information breakthrough. Higher education institutions are reluctant to admit that a digital strategy alone is not enough for a university. In order to remain in demand in the digital age, each institution needs to adhere to a strategic approach that would cover not only the IT sphere, but all the institutional aspects of the university.

The researchers' analysis of the world's progressive systems of higher education has shown that the forms of using digital technologies in education are not chosen arbitrarily based on someone's subjective preferences, but are determined by the socio-economic specifics of the activities of specific educational organizations. Forcing the introduction of digital technologies into the system of higher education in our country without proper technological and methodological training can lead to the use of inexpensive and low-quality models of online learning. Universities that do not have additional resources for creating high-quality digital content and (or) developing online interaction between students and teachers will be forced to use the most accessible 
technological solutions, which often do not provide "deep and meaningful learning" [17]. The fundamental transformation of universities is impossible without improving the digital literacy of the subjects of the educational process in general.

It seems necessary to approach digitalization in a comprehensive manner, simultaneously in all areas: automation of administrative management of the university, increasing the IT competence of teachers and students, development and use of internal and external online courses, a selection of research topics and qualification works in accordance with the needs of the digital economy of the region and the country.

The degree of demand and competitiveness of the university depends on the choice of the "digital university" model. Using modern technologies, universities are able to turn into a real cross-border factory of highly qualified specialists.

\section{ACKNOWLEDGMENTS}

The article was prepared with the grant support of the Russian Foundation for Basic Research, project No.18-2916223.

\section{REFERENCES}

[1] V.D. Nechaev and E.E. Durneva, "«Digital generation»: psychological and pedagogical study of the problem" ["«Cifrovoe pokolenie»: psihologo-pedagogicheskoe issledovanie problem"], Pedagogy [Pedagogika], 2016, vol. 1, pp. 36-45. (In Russ.).

[2] T.A. Antonova, A.V. Vetkina and I.G. Mityunova, "Legal Regulation of Digitalization of The Educational Environment in The Russian Federation", in Proceedings of the Social and Behavioural Sciences EpSBS, 2019, vol. 87, pp. 681-687. (In Russ.). DOI: https://doi.org/10.15405/epsbs.2020.08.02.89

[3] O.B. Tomilin, A.K. Klyueva, E.A. Drugova, I.M. Fadeeva and O.O. Tomilin, "Organizational conflicts in the transformation of universities: Destruam et Aedificabo" ["Organizacionnye konflikty v transformacii universitetov: Destruam et Aedificabo"], Integration of education [Integraciya obrazovaniya], 2019, vol. 23(2), pp. 265-283. (In Russ.). DOI: https://doi.org/10.15507/1991-9468.095.023.201902.265-283

[4] T.V. Nikulina and E.B. Starichenko, "Informatization and digitalization of education: concepts, technologies, management" ["Informatizaciya i cifrovizaciya obrazovaniya: ponyatiya, tekhnologii, upravlenie"], Pedagogical education in Russia [Pedagogicheskoe obrazovanie $\mathrm{v}$ Rossii], 2018, vol. 8, pp. 107-113. (In Russ.).

[5] S. Lyudvig, "Higher education: the experience of an online learning promoter" ["Vysshee obrazovanie: opyt propagandista onlajnobucheniya",] Education issues [Voprosy obrazovaniya], 2018, vol. 4, pp. 167-187. (In Russ.). DOI: https://doi.org/10.17323/1814-9545-20184-167-187

[6] P.A. Bajguzhin, D.Z. Shibkova abd R.I. Ajzman, "Factors influencing the psychophysiological processes of information perception in the context of informatization of education. Science for Education Today" ["Faktory, vliyayushchie na psihofiziologicheskie processy vospriyatiya informacii $\mathrm{v}$ kontekste informatizacii obrazovaniya. Nauka dlya obrazovaniya segodnya"], 2019, vol. 9(5), pp. 48-70. (In Russ.). DOI: http://dx.doi.org/10.15293/2658-6762.1905.04
[7] R.M. Petruneva, V.D. Vasilieva and Y.V. Petruneva, "Digital Students: Myths and Reality" ["Cifrovoe studenchestvo: mify i realnost"], 2019 , vol. 28(11), pp. 47-55. (In Russ.). DOI: https://doi.org/10.31992/08693617-2019-28-11-47-55

[8] O.V. Mihajlov and YA.V. Denisova, "Distance learning in Russian universities: «one step forward, two steps back»?" ["Distancionnoe obuchenie v rossijskih universitetah: «shag vpered, dva shaga nazad»?"], Higher education in Russia [Vysshee obrazovanie v Rossii], 2020, vol. 29(10), pp. 65-76. (In Russ.). DOI: https://doi.org/10.31992/08693617-2020-29-10-65-76

[9] N.V. Dneprovskaya, "Assessment of the readiness of Russian higher education for the digital economy. Statistics and Economics" ["Otsenka gotovnosti rossijskogo vysshego obrazovaniya $\mathrm{k}$ cifrovoj ekonomike. Statistika i Ekonomika"], 2018, vol. 15(4), pp. 16-28. (In Russ.). DOI: https://doi.org/10.21686/2500-3925-2018-4-16-28

[10] V.S. Efimov and A.V. Lapteva, "Digitalization in the System of Development Priorities for Russian Universities: An Expert View" ["Cifrovizaciya v sisteme prioritetov razvitiya rossijskih universitetov: ekspertnyj vzglyad"], University Management: Practice and Analysis [Universitetskoe upravlenie: praktika i analiz], 2018, vol. 22(4), pp. 5267. (In Russ.). DOI: https://doi.org/10.15826/umpa.2018.04.040

[11] E.V. Brodovskaya, A.YU. Dombrovskaya, T.E. Petrova, R.V. Pyrma and A.A. Azarov, "The digital environment of the leading universities of the world and the Russian Federation: the results of a comparative analysis of these sites" ["Cifrovaya sreda vedushchih universitetov mira i RF: rezultaty sravnitelnogo analiza dannyh saitov"], Higher education in Russia [Vysshee obrazovanie v Rossii], 2019, vol. 29(12), pp. 9-22. (In Russ.). DOI: https://doi.org/10.31992/0869-3617-2019-28-12-9-22

[12] V.S. Sharov, "Distance learning: form, technology, means" ["Distancionnoe obuchenie: forma, tekhnologiya, sredstvo"], Bulletin of the A. I. Herzen Russian State Pedagogical University [Izvestiya Rossijskogo gosudarstvennogo pedagogicheskogo universiteta im. A. I. Gercena], 2009, vol. 94, pp. 236-240. (In Russ.).

[13] I.R. Gafurov, G.I. Ibragimov, A.M. Kalimullin and T.B. Alishev, "Transformation of education in higher education during a pandemic: pain points" ["Transformaciya obucheniya v vysshej shkole vo vremya pandemii: bolevye tochki"] Higher education in Russia [Vysshee obrazovanie v Rossii], 2020, vol. 29(10), pp. 101-112. (In Russ.). DOI: https://doi.org/10.31992/0869-3617-2020-29-10-101-112

[14] M. Dzhanelli, "E-learning in theory, practice and research" ["Elektronnoe obuchenie v teorii, praktike i issledovaniyah"], Education Issues [Voprosy obrazovaniya], 2018, vol. 4, pp. 81-98. (In Russ.). DOI: https://doi.org/10.17323/1814-9545-2018-4-81-98

[15] A.M. Galimov and R.R. Hadiullina, "Electronic information and educational environment of the university as a tool for improving the quality of the educational process" ["Elektronnaya informacionnoobrazovatelnaya sreda vuza kak instrument povysheniya kachestva obrazovatelnogo processa"], Bulletin of the Tomsk State University [Vestnik Tomskogo gosudarstvennogo universiteta], 2019, vol. 443, pp. 241-254. (In Russ.). DOI: https://doi.org/10.17223/15617793/443/29

[16] D.A. Andreev, I.V. Andreyanova, I. Bulgakova, M.V. Vasilieva, S.E. Demidova, T.N. Doroshenko, O.E. Kalpinskaya, E.A. Makarova, L.V. Motaylenko, E.N. Naumova, O.S. Petrova, A.Yu. Rozhkova, O.A. Serova, O.A. Sobolev and L.M. Shlyakhtova, "Competence in the digital economy: modern personnel challenge: monograph" "Kompetencii v cifrovoj ekonomike: sovremennyj kadrovyj vyzov: monografiya"], Moscow: RUSAYNS, 2020. (In Russ.)

[17] D.G. Kochergin and E.E. ZHernov, "Experience of digitalization of higher education in the USA" ["Opyt cifrovizacii vysshego obrazovaniya v SSHA"] Professional education in Russia and abroad [Professional'noe obrazovanie v Rossii i za rubezhom], 2019, vol. 2(34), pp. 12-23. (In Russ.). 